\title{
Foliage Mortality of Mountain Big Sage- brush [Artemisia tridentata subsp. vaseyana] in Southwestern Idaho during the Winter of 1976-77
}

\author{
CLAYTON L. HANSON, CLIFTON W. JOHNSON, AND J. ROSS WIGHT
}

\begin{abstract}
Mountain big sagebrush (Artemisia tridentata subsp. vaseyana) in southwest Idaho suffered extensive overwinter foliage mortality during 1976-77 where the normally deep snow cover was lacking. Mortality was 75 to $100 \%$ in areas where snow usually covers dense stands of sagebrush; however, winterkill was slight in areas of usually shallow snow cover. Winter-induced physiologic drought caused by frozen soils, low soil water content, and above average air temperature was the apparent cause of sagebrush foliage mortality.
\end{abstract}

In the spring of 1977 , extensive foliage mortality of mountain big sagebrush (Artemisia tridentata subsp. vaseyana) was evident in the mountainous terrain of southwestern Idaho above the $1700 \mathrm{~m}$ elevation. The affected area is part of the Owyhee Plateau (Tisdale et al. 1969), which includes parts of Idaho, Oregon, and Nevada.

Infestations of aroga moth (Aroga websteri) (Gates 1964), longtailed voles (Microtus longicaudus latus) (Frischknecht and Baker 1972), and gall midges (Diptera cecidomyiidae) (Jones 1971) have been documented as causes of sagebrush kills. Upon careful examination of the affected areas, infestation by insects or rodents was considered unlikely. Other investigators have attributed kills of big sagebrush to severe droughts (Allred 1941, Ellison and Woolfolk 1937, Ferguson 1964, Pechanec et al. 1937, and Reed and Peterson 1961), even though studies have shown that big sagebrush can survive during long periods of low soil water (Branson et al. 1970, 1976; Branson and Shown 1975).

Winterkill of big sagebrush has seldom, if ever, been reported in the literature. However, winterkill has been associated with the mortality of other shrub species, such as fourwing saltbush (Atriplex canescens) (Van Epps 1975), bitterbrush (Purshia tridentata) (Jensen and Urness 1979), and snowbrush (Ceanothus velutinus) (Stickney 1965). These species are found with big sagebrush in southwest Idaho, which suggests that winterkill was a possible cause of mountain big sagebrush mortality during 1976-77. We also noted extensive top kill of snowberry (Symphoricarpos oreophilus) associated with areas of sagebrush mortality. This study was conducted to determine the extent of mountain big sagebrush overwinter foliage mortality and its relationship to winter drought.

\section{Study Area and Procedures}

The study area included 2710 ha in the southeast part of the Reynolds Creek Experimental Watershed in southwest Idaho (Fig. 1). This watershed was selected for hydrologic studies in 1960 to

\footnotetext{
Authors are agricultural engineer, research hydraulic engineer, and range scientist, Northwest Watershed Research Center, U.S. Dep. Agr., Agr. Res. Serv., Suite 116, Boise, Idaho 83705 .

This research is a contribution from the Northwest Watershed Research Center, U.S. Dep. Agr., Agr. Res. Scrv., Bureau of Land Management, U.S. Dep. Interior; and Idaho Agricultural Experiment Station, cooperating.

Manuscript received June $30,1980$.
}

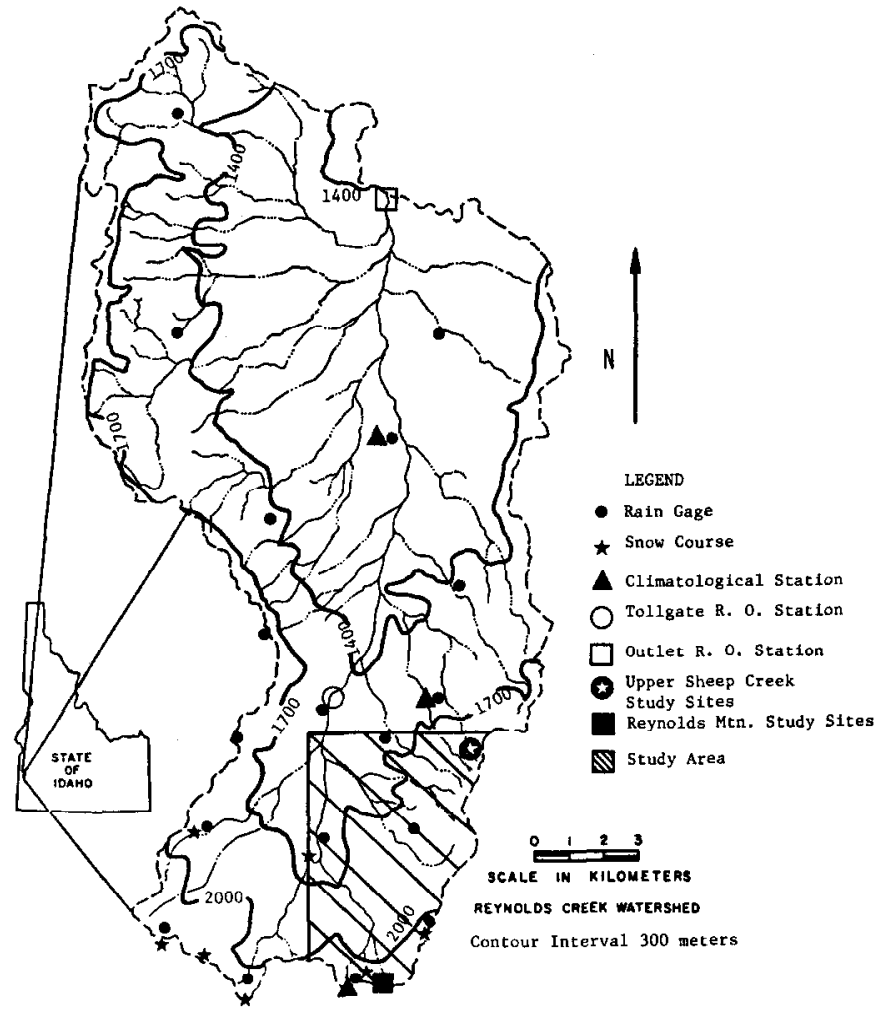

Fig. 1. Reynolds Creek Experimental Watershed.

represent extensive rangeland areas in Idaho and surrounding states (Robins et al. 1965). The study area ranges in elevation from about $1490 \mathrm{~m}$ to $2208 \mathrm{~m}$. The four Soil Associations in the study area are Bakeoven-Reywat-Babbington, Harmehl-GabicaDemast, Searla-Bullrey, and Takeuchi-Kanlee-Ola (Stephenson 1977).

The major plant species of the study area include: Idaho fescue (Festuca idahoensis), Sandberg bluegrass (Poa sandbergii), bearded bluebunch wheatgrass (Agropyron spicatum), needleand-thread (Stipa comata), mountain brome (Bromus marginatus), squirreltail (Sitanion hystrix), sedges (Carex spp.), mountain big sagebrush (Artemisia tridentata subsp. vaseyana), low sagebrush (A. arbuscula), Douglas fir (Pseudotsuga menziesii), quaking aspen (Populus tremuloides), and snowberry (Symphoricarpos oreophilus).

In this study, we did not survey the low sagebrush (A.arbuscula) communities because this species was not killed in 1976-77.

Line transects were established on each vegetation mapping unit, as described by Stephenson (1977). During July and August 
1977, we assessed any mountain big sagebrush plants if $20 \%$ or more of their canopy was intercepted by the transect lines. The percentage of dead foliage was visually estimated, and each plant was classified into one of the following categories: (1) no dead foliage due to winterkill (normal); (2) $<25 \%$ dead foliage; (3) 25 to $50 \%$ dead foliage; (4) 50 to $75 \%$ dead foliage, and; (5) $>75 \%$ dead foliage. Surveyed plants were further classified as being less than or greater than $30 \mathrm{~cm}$ high. Plants or plant canopy that had died before the 1976-77 winter season were not included in the survey. Total herbage production, including annual production of sagebrush plants, was measured on two plots at the Upper Sheep Creek study site and two plots at the Reynolds Mountain study site (Fig. 1).

Figure 1 also shows the locations of precipitation gaging sites, snow courses, and climatological stations where temperature was recorded. Soil water content was measured approximately every 2 weeks at the Reynolds Mountain site for the period 1967 through 1977. Aerial photographs of Reynolds Creek Watershed have been taken during several winter seasons to record snow cover distribution for hydrologic studies.

\section{Results and Discussion}

\section{Climatic Conditions}

Figure 2 shows the record low amount of precipitation during the 1977 water year by comparing 1977 cumulative precipitation values with extreme years, 1965 and 1966, and the 14-year average before 1977. Precipitation during November, December, and January, during the 3 months that normally account for about $40 \%$ of the annual total, was the lowest on record. Precipitation during February and March was about average and April precipitation was the lowest on record. Accumulated precipitation, October I, 1976, through April 30, 1977, was only $31 \%$ of average. May precipitation was about twice the average value and June precipitation was about average, which resulted in above-average forage production.

The small amount of precipitation from November through January resulted in the very little snow cover (Fig. 3) with essentially no snow cover until the end of February. The maximum snow water equivalent for 1977 at the snow course was only $38 \%$ of the long-term (15-yr) average. Because of this shallow snow cover, sagebrush, which is normally covered in the drift areas, was not covered during December and January, and it was not completely covered at any time during the winter.

Soil water content at the Reynolds Mountain sites in October 1976 (Fig. 4) was above average, because of above-average precipitation in September. However, soil water content within the $1.37 \mathrm{~m}$ profile was about $7 \mathrm{~cm}$ below average from November through March.

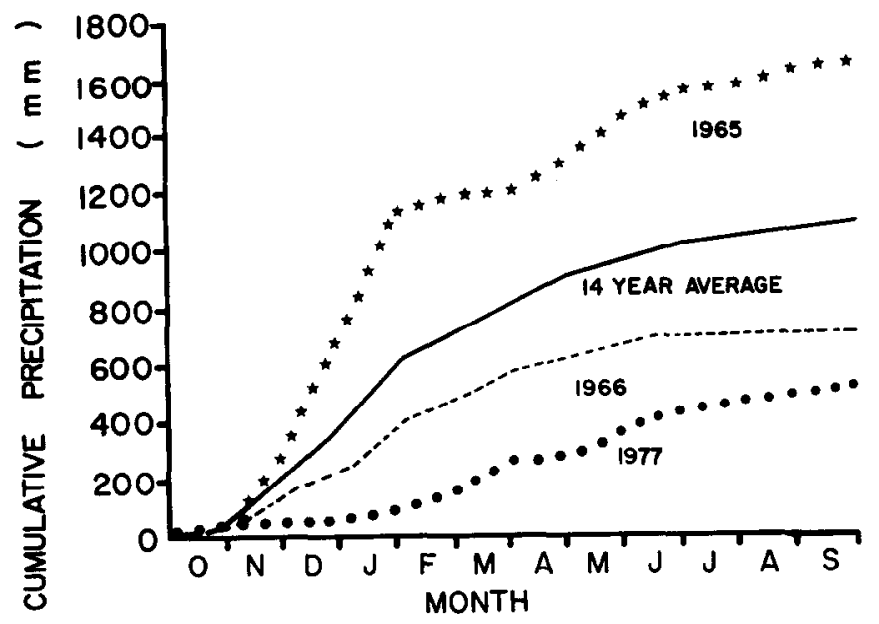

Fig. 2. Cumulative water year precipitation at Reynolds Mountain (elev. $2060 \mathrm{~m}$ ) for 1965, 1966, 1977, and 14-year average before 1977.

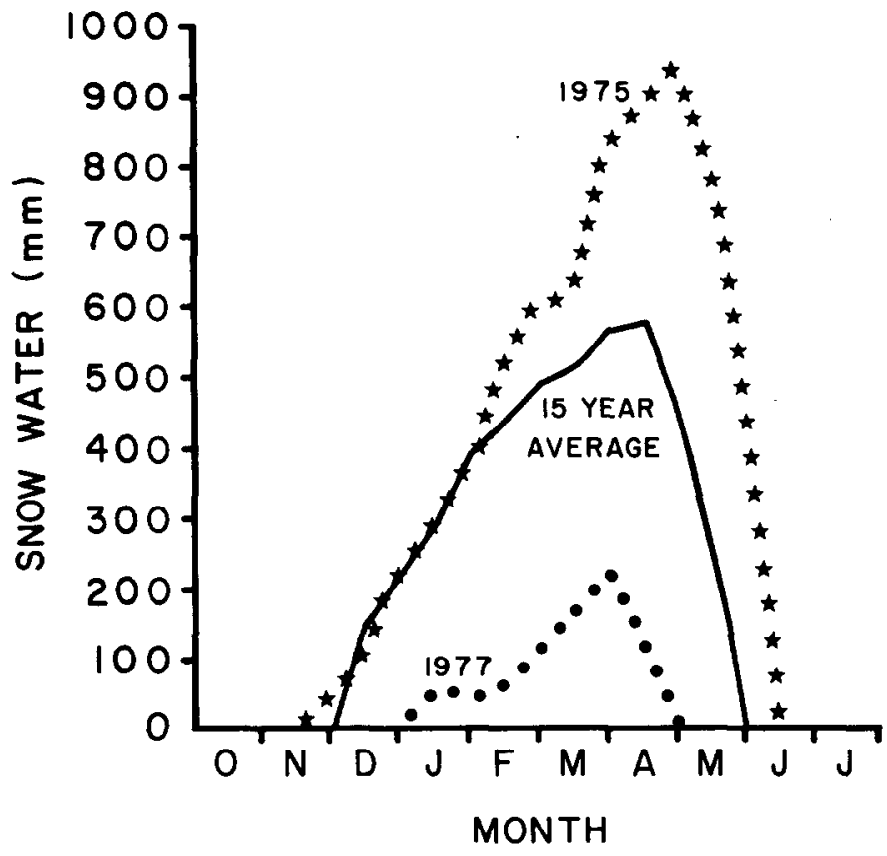

Fig. 3. Water year snow water equivalent at Reynolds Mountain snow course for 1975, 1977, and 15-year average before 1977.

Air temperatures during 1976-77 were 3 to $5^{\circ} \mathrm{C}$ above average from October through December, $1^{\circ} \mathrm{C}$ above average in January, and $2^{\circ} \mathrm{C}$ above average in February. During this same period, the minimum temperature was $-15^{\circ} \mathrm{C}$ I day in November and 2 days in January.

The daily minimum temperatures dropped to $-12^{\circ} \mathrm{C}$ and below for only two periods of 3 to 5 days. The first period was during the last week of November and the other was during the first 10 days in January. Maximum temperatures were 8,7 , and $11^{\circ} \mathrm{C}$ for December, January, and February, respectively, which indicated that there were several freeze-thaw cycles during 1976-77 when the sagebrush plants were not entirely or partly covered by snow as they are during normal years.

Soil frost measurements at the Reynolds Mountain weather station showed that the frozen soil depth was $21 \mathrm{~cm}$ by December 7 and had increased to $53 \mathrm{~cm}$ by Februiary 7 . These records show that the soil was frozen during the period when the snow cover was shallow and temperatures were high enough for plant respiration.

\section{Mountain Big Sagebrush Mortality}

Winterkill affected nearly $90 \%$ of the sagebrush foliage within the study area. No mortality was noticeable below $1700 \mathrm{~m}$ elevation where average annual precipitation is about $380 \mathrm{~mm}$. Between the 1700 and $1900 \mathrm{~m}$ elevation, however, foliage mortality depended on location. At these elevations, foliage was killed on

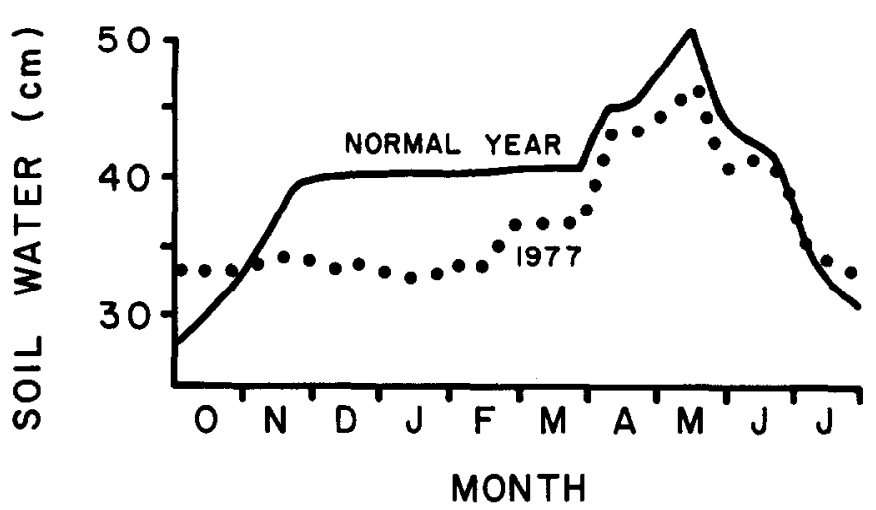

Fig. 4. Soil water content from a composite of several sites at the two Reynolds Mountain study sites (1.37-m profile). 


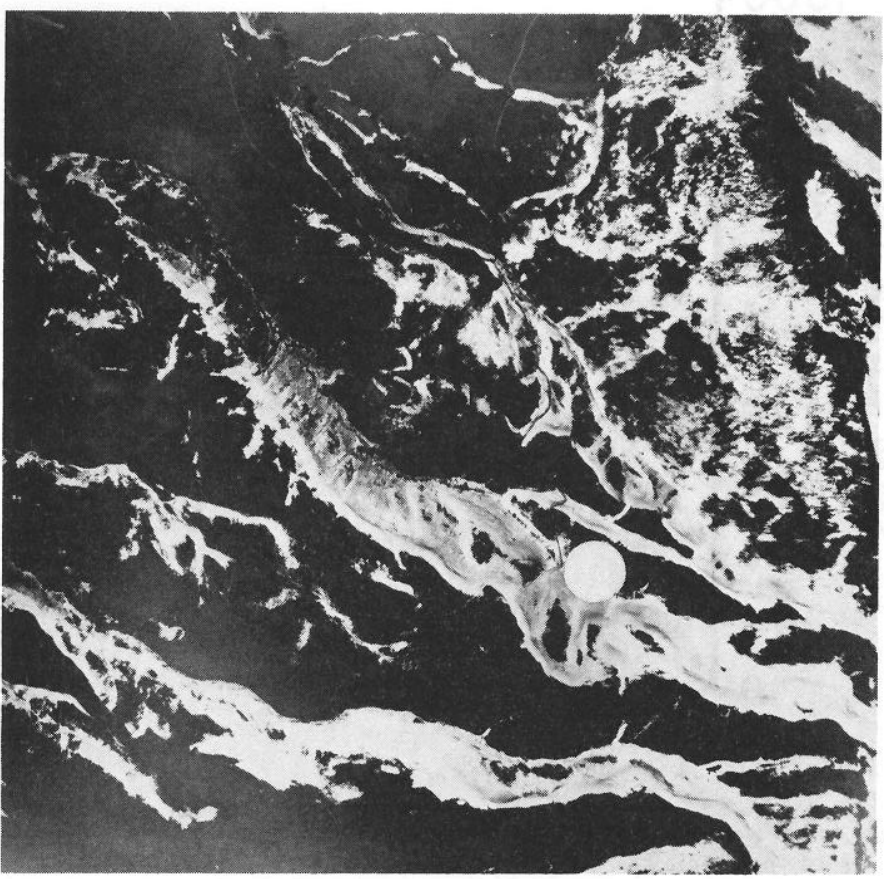

Fig. 5. March 28, 1969 aerial photo of snowdrift areas in the $1700-1900 \mathrm{~m}$ elevation zone. $\mathrm{O}=$ Upper Sheep Creek vegetation study sites.

north-facing slopes that are normally covered by snowdrifts, but were absent during the winter of 1976-77. At these elevations, foliage mortality was almost $100 \%$ where snowdrifts normally exceed $1 \mathrm{~m}$; mortality decreased as the normal snow depth decreased. These differences in snow depth could be seen in the aerial photograph (Fig. 5), taken on March 28, 1969, a near normal snow year. In areas with no snow cover (Fig. 5), there was no foliage mortality.

Above 1900 m elevation, almost all sagebrush plants were damaged. This damage ranged from a small percent of foliage mortality to total plant kill. At this elevation, the entire area normally has

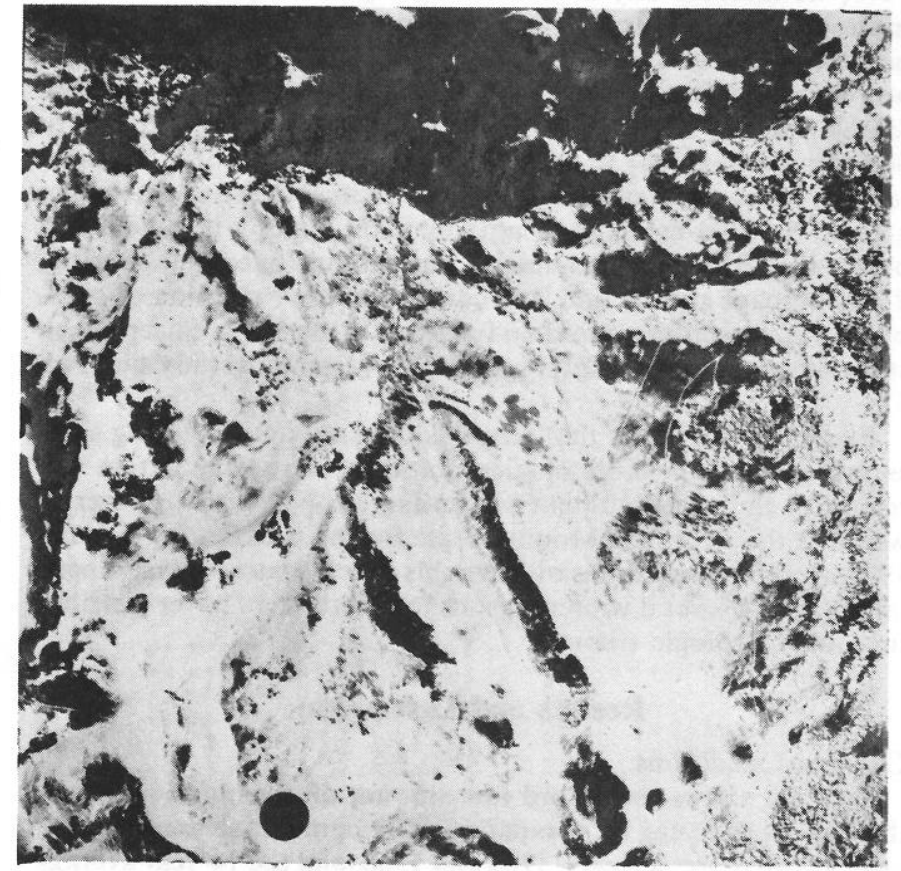

Fig. 6. May 4, 1970 aerial photo of snow cover in the 1900-2200 m elevation zone. $=$ Reynolds Mountain vegetation study sites.

some snow cover, as shown by the aerial photograph taken on May 4, 1970, before spring snowmelt (Fig. 6). Like lower elevations, mortality was most severe in areas where snow normally covers the sagebrush, as shown by the unbroken white area in Fig. 6. In areas where vegetation shows through the snow (Fig. 6), the percent mortality depended on the depth of normal snow cover, with the least damage occurring along the windswept dark colored ridges. Snow-covered areas in aerial photographs (Figs. 5 and 6), taken during normal winter cover conditions, closely coincided with areas of winterkill in 1976-77. At elevations of 1900 to $2200 \mathrm{~m}$, mean annual precipitation ranges from 560 to $1067 \mathrm{~mm}$.

Table 1. Mountain big sagebrush foliage mortality within plant communities and the percentage of the area in each foliage mortality category that makes up the total study area.

\begin{tabular}{|c|c|c|c|c|c|c|}
\hline \multirow[b]{2}{*}{ Plant community } & \multicolumn{5}{|c|}{ Foliage mortality category $(\%)^{\prime}$} & \multirow[b]{2}{*}{ Area (ha) } \\
\hline & Normal & $<25$ & $25-50$ & $50-75$ & $>75$ & \\
\hline $\begin{array}{l}\text { Mountain big sagebrush } \\
\text { (A. tridentata subsp. vaseyana) }\end{array}$ & 12 & 8 & 3 & 10 & 67 & 381 \\
\hline $\begin{array}{l}\text { Bitterbrush } \\
\quad \text { (Purshia tridentata) }\end{array}$ & 100 & & & & & 40 \\
\hline $\begin{array}{l}\text { Cheatgrass } \\
\text { (Bromus tectorum) }\end{array}$ & 100 & & & & & 152 \\
\hline $\begin{array}{l}\text { Curlleaf mountain mahogany } \\
\text { (Cerococarpus ledifolius) }\end{array}$ & & & & 100 & & 29 \\
\hline $\begin{array}{l}\text { Douglas fir } \\
\text { (Pseudotsuga menziesii) }\end{array}$ & & 25 & & 75 & & 76 \\
\hline $\begin{array}{l}\text { Idaho fescue } \\
\text { (Festuca idahoensis) }\end{array}$ & 10 & 90 & & & & 383 \\
\hline $\begin{array}{l}\text { Quaking aspen } \\
\text { (Populus tremuloides) }\end{array}$ & & & & & 100 & 38 \\
\hline $\begin{array}{l}\text { Snowberry } \\
\text { (Symphoricarpos oreophilus) }\end{array}$ & 4 & 12 & 6 & 22 & 56 & 1585 \\
\hline $\begin{array}{l}\text { Sierra juniper } \\
\text { (Juniperus occidentalis) }\end{array}$ & & & & 100 & & 25 \\
\hline $\begin{array}{l}\text { Whiteleaf sanbar willow } \\
\text { (Salix argophylla) }\end{array}$ & & & & & 100 & 1 \\
\hline $\begin{array}{l}\text { Percent of the total study area that each } \\
\text { foliage mortality category represents } \\
\text { and the total area in hectares. }\end{array}$ & 12 & 22 & 4 & 19 & 43 & 2710 \\
\hline
\end{tabular}

' Percentage was calculated by dividing the number of plants in each foliage mortality category by the total number of plants surveyed and multiplying by 100 . 


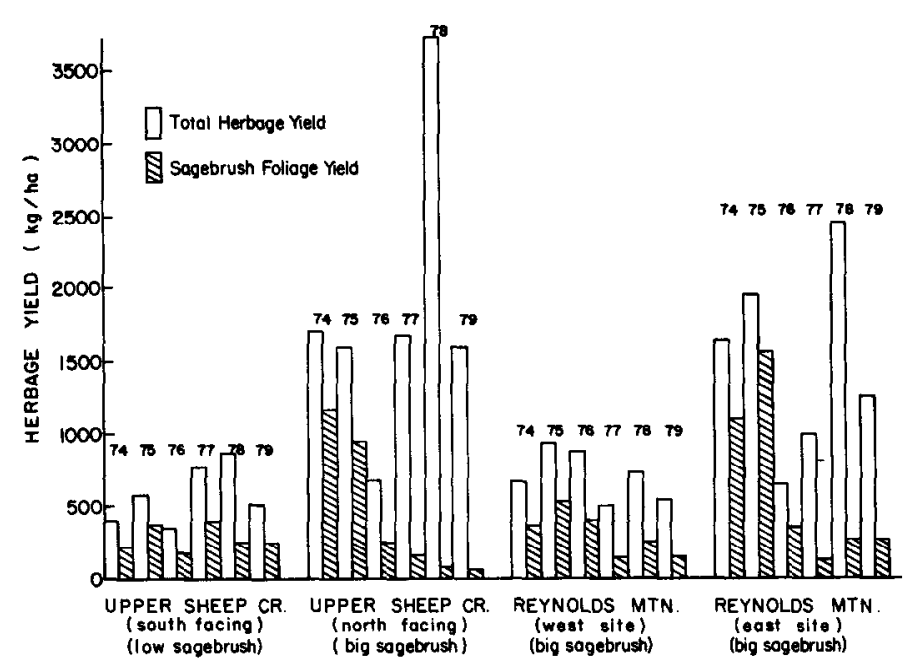

Fig. 7. Herbage yields at four sites for 1974 through 1979.

Table 1 summarizes mountain big sagebrush foliage mortality by plant community. Mortality ranged from none for the bitterbrush and cheatgrass communities, which were located at the lower elevations of the study areas, to $100 \%$ mortality in the snowdrift areas where the quaking a spen and willow communities were located. Mortality rates were also very high for the Douglas fir, mountain mahogany, juniper, and snowberry communities. Of the sagebrush plants surveyed within the study area, 12, 22, 4, 19, and $43 \%$ respectively, were classified in the normal, $<25 \%, 25$ to $50 \%$, 50 to $75 \%$, and $>75 \%$ foliage mortality categories (Table 1). This represented about a $54 \%$ reduction in the foliar cover of sagebrush over the entire study area.

Herbage yield data (Fig. 7) also showed the extent and locations of mountain big sagebrush foliage mortality from winterkill. The Upper Sheep Creek (south-facing) site is across the draw from the Upper Sheep Creek (north-facing) site. Low sagebrush is the most abundant species on the south-facing site and mountain big sagebrush is the major species on the north-facing site. As indicated in Figure 7, weather conditions during the 1976-77 winter did not affect low sagebrush, but killed most of the mountain big sagebrush foliage on the north-facing site. The north site is located near the center of an area where a snowdrift normally covers all the vegetation. Snow cover on the south site is normally very shallow, because the snow is blown off.

Mountain big sagebrush is the most abundant brush species on both Reynolds Mountain sites. Sagebrush plants on the east site were much taller than those on the west sitc, because a decp snowdrift normally covers this area. Snow depth on the west site coincides with sagebrush height, because of drifting. Foliage mortality at these two sites (Fig. 7) followed the same trend as those at the Upper Sheep Creek site, where severe mortality was associated with the areas normally covered by snow.

\section{Probable Causes of Mountain Big Sagebrush Winterkill}

Winterkill is often associated with two factors: (1) extremely low temperatures that affect plant tissue, and (2) drought. Weiser (1970) and Burke et al. (1976) indicated that either very low temperatures or subfreezing temperatures, when plants are not in their "hardy" states, are lethal to plants. During the 1976-77 winter, monthly temperatures were above average, but were low enough to induce a normal winter-hardiness state. Daily minimum temperatures were not excessive and the continuous temperature record does not show any periods of rapidly decreasing temperature. Thus, it seems unlikely that low temperatures alone da maged plant tissues.

Unavailability of soil water can be caused by low soil water content and frozen soil conditions. During 1976-77, soil water was below average from November through March (Fig. 3), but there were other years when soil water content during the fall and early winter was lower, with no noticeable sagebrush loss. Thus, low soil water per se does not seem to be the factor that caused the observed winterkill.

More likely, the combination of warm days, low soil water content, and frozen soils was responsible for the sagebrush winterkill. These conditions, as discussed by Daubenmire (1959), Richards et al. (1952), and Vasil'yev (1956), can cause a severe physiologic drought, because plant roots are not able to supply enough water to meet the plants' transpiration demands.

Mountain big sagebrush plants that are not normally covered by snow seem to have evolved a dormancy condition that enables them to withstand winter-induced physiologic droughts. However, mountain big sagebrush plants that have evolved in an environment where snow cover normally prevents the soils from freezing and provides a protective plant cover that reduces transpiration demand are apparently not acclimated to long periods of winterinduced physiologic drought.

\section{Literature Cited}

Allred, B.W. 1941. Grasshoppers and their effect on sagebrush on the Little Powder River in Wyoming and Montana. Ecology 22:387-392.

Branson, F.A., R.F. Miller, and I.S. McQueen. 1970. Plant communities and associated soil and water factors on shale-derived soils in northeastern Montana. Ecology 51:391-407.

Branson, F.A., R.F. Miller, and I.S. McQueen. 1976. Moisture relationships in twelve northern desert shrub communities near Grand Junction, Colorado. Ecology 57:1 104-1 124.

Branson, F.A., and L.M. Shown. 1975. Soil-moisture stress as related to plant-moisture stress in big sagebrush. J. Range Manage. 28:212-215.

Burke, M.J., L.V. Gusta, H.A. Quamme, C.J. Weiser, and P.H. Li. 1976. Freezing and injury in plants. Annu. Rev. Plant Physiol. 27:507-528.

Daubenmire, R.F. 1959. Plants and environment, a textbook of plant autecology. John Wiley \& Sons, Inc. New York. 422 p.

Ellison, L., and E.J. Woolfolk. 1937. Effects of drought on vegetation near Miles City, Montana. Ecology 18:329-336.

Ferguson, C.W. 1964. Annual rings in big sagebrush. Univ. of Arizona Press. Papers of the Laboratory of Tree-Ring Research. No. 1. 95 p.

Frischknecht, N.C., and M.F. Baker. 1972. Voles can improve sagebrush rangelands. J. Range Manage. 25:466-468.

Gates, D.H. 1964. Sagebrush infested by leaf defoliating moth. J. Range Manage. 17:209-210.

Jensen, C.H., and P.J. Urness. 1979. Winter cold damage to bitterbrush related to spring sheep grazing. J. Range Manage. 32:214-216.

Jones, R.G. 1971. Ecology of Rhopálomyia and Diarthronomyia gall midges (Diptera: cecidomyiidae) on sagebrush, Artemisia spp. in Idaho. Ph.D. Diss. Univ. of Idaho, Moscow. $121 \mathrm{p}$.

Pechanec, J.F., G.D. Pickford, and G. Stewart. 1937. Effects of the 1934 drought on native vegetation of the upper Snake River Plains, Idaho. Ecology 18:490-505.

Reed, M.J., and R.A. Peterson. 1961. Vegetation, soil and cattle responses to grazing on Northern Great Plains Range. U.S. Dep. Agr. Forest Serv. Tech. Bull. 1252. 79 p.

Richards, S.J., R.M. Hagan, and T.M. McCalla. 1952. Soil temperature and plant growth, p. 303-480. In: Shaw, B.T. (ed.) Soil physical conditions and plant growth. Acad. Press Inc., New York. 491 p.

Robins, J.S., and L.L. Kelly, and W.R. Hamon. 1965. Reynolds Creek in southwest Idaho: An outdoor hydrologic laboratory. Water Resources Res. 1:407-413.

Stephenson, G.R. 1977. Soil-geology-vegetation inventories for Reynolds Creek Watershed. Idaho Agr. Exp. Sta. Misc. Ser. No. 42.73 p.

Stickney, P.F. 1965. Note on winter crown kill of Ceanothus velutinus. Proc. Montana Academy of Sci. 25:52-57.

Tisdale, E.W., M. Hironaka, and M.A. Fosberg. 1969. The sagebrush region in Idaho, a problem in range resource management. Idaho Agr. Exp. Sta. Bull. 512 . 15 p.

Van Epps, G.A. 1975. Winter injury to fourwing saltbush. J. Range Manage. 28:157-159.

Vasil'yev, I.M. 1956. Wintering of plants. Ed. English translation, Jacob Levitt. Translated from the Russian by Royer and Roger, Inc., Amer. Inst. Biol. Sci., Washington, D.C. 300 p.

Weiser, C.J. 1970. Cold resistance and injury in woody plants. Science 169:1269-1278. 